\title{
Ikwuano Women in 1929 Women's Protest: A Recipe from Women War in Ancient Israel (Judges 4:4-24)
}

\author{
Ohaeri Nnaemeka Ndubuwa \& Asukwo Edet Oko \\ https://dx.doi.org/10.4314/ujah.v22i2.7
}

\section{Abstract}

This paper focused on the uniqueness of Ikwuano women in terms of their contributions towards economic and political development, particularly around 1929 events. It aimed at accentuating the valiant role of Ikwuano Women in their gallant protest to claim their rights against household taxation by the British Colonial rule through the Warrant Chiefs. The research adopted a historical method to trace the role of women in the Ancient Israeli war in Judges 4:4-24 which applies to the Aba Women Protest. A historical examination shows that the 1929 so-called 'Aba Women Riot' was an Igbo women's traditional demonstration that allowed women to express their disapproval of any policy that infringes their human rights at that time. Foreign publishers used derogatory dictions such as riot, revolt, and war and later termed it "Aba Riot", excluding women, probably because they were oblivious of the aforementioned protest in Igbo tradition or that they denied political fault of household taxation policy and assault to women as colonialists. The findings unveiled that the contributions of Ikwuano women to the political and economic development of Nigeria cannot be overemphasized, just as Deborah's and Jael's exploits in Ancient Israel cannot be underestimated. The paper also investigated that the so-called Aba Women Riot of 1929 emanated from a clan called Oloko, in Ikwuano under Old Aba Province, as a protest which spread to Aba, Owerri, Calabar, and other Eastern Region of Nigeria. It gained international attention that resulted in 
the cancellation of Women's Taxation, the improvement of the national economy, and abrogation of the Warrant Chief System. The paper recommended the empowerment of Ikwuano Women, adequate support of the Government in revitalizing the production of cash crops in Ikwuano through mechanization and mass employment of indigenous youth in the aforementioned Institutes to alleviate poverty in the area. Lessons should be learned from women's war in ancient Israel contained in Judges 4:4-24, which reveals the inherent ability of women to promote national economy, peace, politics, and defense against external aggressions.

Keywords: Accentuating, Ikwuano, Women, Protest, Riot, and Economy

\section{Introduction}

The accounts of creation reveal that women are helpmates for men in all areas of life. This implies that the potentials of Ikwuano women cannot be overemphasized if the Nigerian economy must be improved through agriculture. Their hard work in agriculture to produce food and cash crops for exportation such as Cocoa, Rubber, Maize, Cassava, Palm Oil, Cannel, Raffia/Palm wine, and Clay for Ceramics was highly commendable. Ikwuano's fertile land necessitated the idea of the Federal Government to subsequently establish the University of Agriculture known as Michael Okpara University of Agriculture Umudike and National Root and Crop Research Institute Umudike in Ikwuano land, with Golden Guinea Brewery Industry close to Ikwuano-Ikot-Ekpene Road Umuahia. Ikwuano Women were known for assisting their male counterparts in politics and agriculture to boost the national economy. Historically, their background contributions in "Aba Women Riot" led to the abrogation of household taxation and 
oppressive warrant chief method of Indirect Rule which nearly crippled the national economy in 1929 cannot be overemphasized. This paper attempts to showcase the potential power of women in the political and economic attainment of a nation with lessons from Judge 4:1-24 and remote historical facts of Aba Women Riot in 1929.

\section{Ikwuano-Igbo Ethnography}

The history of Ikwuano as stated in the Memorandum (1975) which was a request for the creation of Ikwuano Local Government Area under the then Imo State narrates that Ikwuano is made up of four kindred clans known as Oboro, Oloko, Ibere, and Ariam. The earliest immigrant into Oboro and Ibere areas came from Bende, Ngwa, and Ukwa in the Old Aba province. The settlers in Oboro defeated the Ibibio aborigines at Mbiopong, settled first at Ahiafor, and later moved down to Ahuwa where they are living till this day. Some of the Ibibio of Mbiopong retreated to their kins at Nkari. Some retired to a little outpost about a mile southwest of Mbiopong and that settlement is known today as Obunta.

Onyirimba (2001) notes that the early immigrants of Ahuwa came with two deities: Ikenga Oboro, a male deity, and Ala Oboro the wife (goddess). When the priest of Ala Oboro died, his wife whom the priest had married from the defeated people of Mbiopong ran back to her village with the deity. Before now Ikenga Oboro had become a terror to the people of Ahuwa who now would gladly be rid of it. Thus, when Ala Oboro was taking to Mbiopong, Ahuwa village readily acquiesced, and while they were seeking to transfer Ikenga's shrine to Mbiopong, they directed all people who came to offer sacrifices to Ikenga to send them to Ala Oboro where Ikenga might as well enjoy the sacrifice with his wife. In this way, 
Mbiopong now Isiala, the home of the aborigines of Oboro became the capital of Oboro and headquarters of Ikwuano Local Government Area.

The immigrants into Ibere lived away from Ahiafor and also settled at the village of Mbinyang after overpowering the Ibibio settlers. A dominant element of the population settled down at this Mbinyang (now Isialalbere) which today is still the seat of the ancestral shrine of Ibere. Later on, in history, a preponderant population immigrated from Bende, Aro, and Abam villages and settled in Oboro and Ibere villages of Ahuwa, Ntalakwu, Ekebedi, Umuigu, Amaoba, Ndoro, Ogbuebulle, Ekebedi, Iberenta, and Ngwugwo among others. They soon became the dominant element of the population in Oboro and Ibere.

However, the assimilation of the original inhabitants did not altogether erase their heritage of kinship with the Annang. An instance of this is the existence of the contemporary Usoro festival at Ifa Nkari in Ini L.G.A then in Uyo province of Akwa Ibom State to which people from the villages of Mbiopong and Mbinyang pay their traditional homage.

History disclosed that Ariam-Usaka and Oloko belong to the same family as Isuogu. Ariam comprising Ariam, Ekpiri, and Usaka families originally, came from Ugwuala in Abam and Usaka from Oraobara clan also in Abam. Ariam now consists of seven villages namely Ariam Ala-Ala, Ariam Elu-Elu, Obeama, Ndiorie, Ekpiri Elu-Elu, Azunchai and Ekpiri Ala-Ala. The earliest immigrants to Ekpiri came from Ubaha under Nsulu Ngwa popularly called Umu Osaji in the old Aba province. They drove the Annang inhabitants and settled where they are today. Ekpiri Ala-Ala was founded by a very tough man named Onyeike Ukwumbe. It is important to note that Ariam and his brother Usaka 
compelled Annang inhabitants to run away towards NtoNdang and ItaIkpo, while they first settled at Ariam Ala-Ala and later spread to Ariam Elu-Elu.

Oloko, the fourth clan of Ikwuano, was originally known as Afa from Abam in Bende. Afa, Usaka and Ariam came from the same Isuogu origin. The later settlers at Oloko came from Abam in Bende. They settled at Ihu-uro, a site between Oloko and Amizi villages. Onyirimba (2001) avers that Ihu-uro is still the site of their ancestral shrine. From there they moved to north-westwards and south-westwards driving away from the Annang of Otoro and Nkari. They later built ten villages of Ahaba, Oloko, Awomukwu, Umugo, Azuiyi, Amizi, Otoro Nchara, Akanu Nchara Akanu, Obuohia Okike and Usaka Eleogu.

The people of Ikwuano and Bende speak the same dialect with slight variations. They have a common greeting, Ndewo, $\mathrm{Ka}$ and welcome visitors with kola and raffia wine. The population according to the census in 1991 reads about 60,000 people with a land mass of about 600 square kilometres. Ikwuano is known for cultures and arts which include Ekpe, New Yam (Iri-Ji) and Afo Amaghi Onuma festivals. Their cultural dances are Eketensi ritual dance, Oro, Ikperikpeogu (war dance) Uko and so on. They also have Oba and Ekpe societies while traditional marriage is held in high esteem. The occupation of Ikwuano people is agriculture (peasant farming) while their religion was African Traditional Religion before the advent of Christianity in 1909 according to Iheukwumere (1986). Politically they are peaceful and mature. Recently Ikwuano people have embraced civilization with Michael Okpara University of Agriculture Umudike (MOUAU) and National Root Crops Research Institute (NRCRI) Umudike among 
other social amenities and infrastructural developments situated within her territory.

\section{Traditional Rights of Ikwuano-Igbo women}

Man as a social being respects mutual rights and interests of one another to maintain social justice. Social justice must be practically sustained to promote unity, peace, and progressive relationship. Igbo culture upholds the sanctity of life and respect for human rights. Okafor (1992) opines that human rights in Igbo culture are concrete social phenomena and not abstract concepts. This philosophy explains why Ikwuano-Igbo women would collectively take a brave protest to sit on any offender that attempted to bastardize their human rights. Again, their impetus is consolidated on the belief that ala the earth goddess which Madu (2004) describes as the source of life and fertility defends women and reacts against their oppressors. Thus Ikwuano-Igbo women sit on somebody (Umunwanyi Ipuru madu), the person must quickly respond positively to their disciplinary measures or be ready for afflictions from Ala- the earth goddess. The affliction may be in form of illness, barrenness, madness, bad luck, untimely death, or reoccurrence of bad omen in the family of the culprit. Therefore, the traditional rights of Ikwuano women are respected in the community especially in Ekebedi Oboro village where the researcher spent his early life.

Nmah (2003) explains that traditional rights of Igbo a woman start from birth and cuts across her family association, social marriage, matrimony, property, life in the society, and widowhood. In infancy, the girl child has the right of protection from the parents and the community as she grows to adolescence, hence the Igbo adage: Nwa bu nke oha (a child belongs to the 
community). Assault of any kind, incest, and rape are taboo with a ritual for cleansing. An Igbo girl can own an economic tree of which root her umbilical cord was buried. Such a tree could be called epe-alo if it is an orange tree. She also has right of belonging to associations like Umu-Ada, Umu-Okpu (daughters Associations of the family and legitimate family daughters' gathering), Out Ogbo (age-grade), Out Umuagbogho (Village daughters or girls Association), out Umunwanyi aluru alu (married women association) and Ogbako Umunwanyi (Community Women Association).

An Igbo woman joins these associations by initiations by age, marital status, and merit. They hold meetings; do sanitation (weeding) of the road, farm, and stream paths. They organize dancing competitions and entertain the community during olili madu (burial ceremony), Iri Ji (New Yam Festival), Igba-nkwu Nwanyi (traditional marriage), and other social gatherings. They observe rules and regulations with sanctions to the offenders. They as well contribute to the developmental projects and settle disputes especially with early warning methods as notes by Nwanegbo (2005). In the same vein, women have the right to settle a dispute among their age grade, members of the association, wives, and village members as the custom allows them. Nmah (2003) asserts that the Igbo women's advice during village dispute settlement is usually "Ndi di anyimezienu" (Our husbands please settle the dispute or let peace reign). They advocate peace in the community. Ikwuano women have the right to be married without discrimination of the Osu Caste System. This implies that Osu Caste System does not exist in Ikwuano as seen in some places like Isuochi, Nneato, and Okigwe in the olden days. Legitimate marriages attract certain privileges and benefits for the bride in 
terms of domestic gifts like kitchen utensils and wrapper; while illegitimate marriages bring shame and stigma to the family. Wives own their husband's kitchen; assist in farming and rearing animals like fowls, etc. They plant crops like cocoyam, melon, maize, Pumpkin, cassava, pepper and garden egg. Ikwuano women learn to cook some traditional or cultural food such as Ofe Ukazi, akpuruakpu elile (molded melon) and ofe achara with okponaban (special oil extracted from the palm fruits direct at the cooking point. Not processed oil). Eku na oku (wooden and clay spoon and pot respectively) are used for eating such traditional food. Again, sexual rights are enjoyed with their husband alone, otherwise, they face a penalty for adultery. Beattie (1980) avers that sexual rights are transferable to a woman's potential offspring but in Ikwuano wives can acquire and dispose of property with the consent of their husbands in a normal circumstance, otherwise the reverse may occur especially with movable personal property. Ikwuano women possess the religious right to participate in women's prayer in the community (Ekpere Umunwanyi) at the village square and junctions and boundaries. Arinze (1970) observes that communal religious prayer of women is more important than private prayers. Nmah (2003) notes that women enriched from the Spirit of Agwu can be excluded from Ekpere Umunwanyi. However, women are generally excluded from entering the inner parts of shrines in Igbo land as underscored by Arinze (1970). Nassau in Arinze (1970) avers that women pray with sighs when they are infrequent sorrow for the intervention of the spirits and ancestors. Ikwuano women do not conduct rituals except to cry and deposit food beside the grave of their late husbands when humiliated as widows or given instruction to do so in the dream. Nmah (2003) reiterates that it is taboo for an Igbo woman to conduct rituals, especially in places 
like Ngwa, Isuikuato, Mbano, Awka, and Abakaliki, though female native doctors make their private sacrifices as in Edda, Afikpo, and Okigwe.

Nevertheless, widows have the right to inherit their husbands' property including their economic trees and plants until they remarry or die. Their sons in turn inherit their father's property when they come of age. In some Igbo cultural practices like Mbano and Owerri, a widow has no right to reap kola nuts, Oroko and Raffia, or Palm trees except if they were legally given to her by her husband in his lifetime according to Obi (1977). Igbo women do not have the right to eat gizzard, tail, anus, and head of meat. Women do not break kola nut $(O j i)$ and cannot become revered ancestors to receive a pouring of libation. They cannot also pour libations and make incantations. A male has the prerogative to perform rituals, even if he is a child, he can be invited to touch a kola nut before women can eat or share in the absence of a mature man.

\section{Roles of Ikwano Women in National Economic Development} Afigbo (1982) opines that "In the pre-colonial Igbo society, agriculture was the most important economic activity concerning both the number of people engaged in it either on a full or part-time basis and to the prestige attached to it" (p. 124). The importance of agriculture to the sustenance of life and economic development in Nigeria cannot be over-emphasized. Hence, the efforts of the Federal government and several agencies in the development of agricultural policies and programmes, to increase food production in the nation. Ikwuano has vast areas of arable land with fertile soil. The people of Ikwuano are the main producers of food in the state. 
They produce Yams, Cassava, Garri, Cocoyams, and Plantains, Banana, Citrus fruits, and Vegetables.

Onyirimba (2001) states that Ikwuano is one of the largest primary producers of cash crops. These cash crops include palm produce and cocoa. Ironemenefu (2006) contributes that Ikwuano ranks second to Ikom in Cross River State in the production of cocoa in the Eastern states. It was in appreciation of this unique contribution to the national economy that Ibere roads were tarred at the instance of the then Marketing Board. Their palm kernel also forms a high percentage of the State's output. Others include kola, coconut, and so on.

The volume of raffia and palm wine being exported from Ariam in Ikwuano on daily basis covers an average of 40 tonnes or 15,000 litres approximately. An output of such level motivated the then Ikwuano/Umuahia Local Government Authority to establish an industry where palm wine could be preserved and bottled. Raffia or palm wine from Ikwuano is still being regarded by most people as the best east of the Niger. At present, there are three privately owned palm oil factories in Ikwuano, namely: Aperch Enterprises Nigeria Limited, Nchara, Ueco Palm Oil Mill, Ibere, and Johnny Kelle Farms Limited, Ariam. According to Orji (1991), while the men harvested palm trees, shredded their fruits, and pounded them when boiled, the women extracted the oil, cracked the nuts of the palm kernels, and sold the palm produce. They either sold the produce at the exchange centres nearest to them or local agents of European merchants with their firms at Aba, Umuahia, Oron, Uyo, and other designated towns. About $60 \%$ of homes bring palm oil to the market every week and the output stands at 25 tons weekly. The state capital, Umuahia, largely depends on Ikwuano for its palm oil. Some years ago, Ikwuano women used to carry their oil to Mbawsi, 
Uzuakoli, Umuahia, and Aba to sell but today they travel up to Kano, Lagos, Maiduguri, and Enugu to supply their produce. Onyirimba (2001) observes that the grade of palm oil from Ikwuano is the best quality anybody can see in Nigeria because of their method of processing it. Okoro (2006) is of the view that the women kept the proceeds from the sales of the palm kernels and gave that of the palm oil to their husbands. Through this way, they were able to improve their financial standing, thereby empowering themselves economically. They also rear livestock such as sheep, goats, rabbits, pigs, ducks, dogs, and poultry.

Furthermore, Ironemenefu (2006) comments that Ibere clan of Ikwuano has good rivers which are potentially rich for fishing. Such rivers like Akoo within the Oruo communities, Iyi Oba, and Ehie rivers could be converted to fish ponds thereby increasing the sources of protein and revenue in Ikwuano. He maintains that basketry was widely spread in the clan and was practiced mainly by young boys of eleven years and above. The product of this industry includes ide, aziza, nkpo, ngara, epete and abo which were used for a variety of house-hold chores. It should be noted that a primary source of this materials is from palm tree. There were other crafts such as ikpa-ute, (mat weaving) used for sleeping and for drying cereals crops such as maize, akidi(local bean), and $u k w a$ (breadfruit).

A sizeable quantity of timber produced in Abia state comes from Ikwuano forest. Places like Okwe and Ibere have Rubber plantations. There have natural forests on which the people always depended for their traditional occupations such as herbal medicine and hunting. Many wild animals are killed and caught during hunting for economic significance. 
Ironemenefu (2006) notes that a large deposit of kaolin is available in various parts of Ikwuano which has been serving the ceramic industries in the Eastern, Western, and Northern parts of the country. It is still speculated that there are petroleum and coal deposits in Ikwuano. The quality of kaolin found in Ekebedi, Ogbuebulle, Awomukwu, Ndoro, Okwe, Amawom, Umudike and all villages of Ibere is enormous.

\section{Women War in Ancient Israel}

The Bible is androcentric in the sense that it ascribes headship to man, probably because the woman was created out of the man and for the sake of man in the account of creation (Gen 2:21-23). However, a theological consideration of the creation of mankind (Adam) as the image of God in the first account of creation (Gen $1: 27$ ), presents both male and female equally with peculiar features of different sexes as the nature of God. Pfeiffer, and Rea (2003) observe that the Hebrew culture in Ancient Near East regarded women as secondary in legal position as part of man's property (Deut. 31:14-15, Ruth 4:5,10) and this explains why daughters did not receive an inheritance after the demise of their fathers (Num 27:1-8).

Obijole (2019) quotes Rabbi Jeshuaben Elaj a Jewish scholar of C. $150 \mathrm{AD}$ concerning the discrimination of women in Ancient Israel, thus: " I thank thee O Lord, that Thou hast not made me an unbeliever or uncivilized, thou has not made me a woman or a slave but has made me according to thy image". This statement shows that women were classed along with a slave, children, the uncivilized or unbelievers in Judaism. In Ancient Israel, especially during the Patriarchal era, women were placed under men and were limited to domestic roles and motherhood. Negatively, they were 
seen as being responsible for sexual temptation and sins. On the other hand, some Jewish writings also render examples of good and resourceful women that made positive impacts in their generations. Proverbs 31 presents a woman of honour whose industry, diligence, entrepreneurial skill, and productivity are worthy of emulation. Swidler (1979) agrees that the leadership role of women in the Old Testament, cannot be overemphasized in the sense that women like Huldah and Miriam served as prophetesses in both the Tabernacle and Temple (Exodus 38:8). Miriam worked with Moses and Aaron as a prophetess (Micah 6:4), Deborah prophetically led Barak to direct the Israeli army in Judges 4:6 and Huldah was the prophetess during Josiah's reform (2 Kings 22:8-20, 2 Chron 34:14-28).

Falusi (1976) citing Josephus observed that God is described in female imagery to portray leadership skills and honour bestowed on women in the Old Testament. God depicted in the maternal image as a 'wet nurse' in Numbers 11:12, provider and attendant of birth in Deut 13:18, Isaiah 42:14, 46:3-4, and as a feeder of a child who instructs how to walk in and as a physician that heals the child's wound in the prophecy of Hosea. Meyers (1988) opined that women held leadership offices as rulers of synagogues in ancient Judaism. Again, the evidence of Job's three daughters who speak angelic languages in the Testament of Job portrays that women performed significant religious roles in the ancient era. Etymologically, the Hebrew word 'ishsha is thought to be derived from a root '- $n$-sh which means "to be soft or delicate", a contrasting meaning of 'ish derived from a root '-y-sh which denotes "to be strong". This etymological consideration might have necessitated the biblical rendering of woman as weaker vessels under the authority of man in the priority of creation and not on superiority (1 Tim 2:12-13). Women, therefore, became man's 
partner and Help Mate endowed with emotional gifts and sensitivities for intuitive understanding of situations and feelings of other people.

This biblical ideology is not far-fetched in Igbo religious culture where women are restricted in certain rituals. Just as women were not counted during a census in Ancient Israel, Igbo culture too does not permit the census of women for taxation, hence, the traditional authority and audacity of Ikwuano women to protest for their human rights against the imposition of taxation on women, children and livestock in 1929 by the British colonists. This protest was published as a women's riot or women's war by foreign authors who were oblivious of the traditional rights of Igbo women. It is important to note that there are similarities between Igbo and Jewish cultures. Therefore, the linkage of Igbo origin to biblical Jewish culture cannot be overemphasized and the view of Adamo (2007) on the African presence in the Bible should not be underrated but be critically considered without bias. In the same vein, the accentuation of women's war in Ancient Israel under the roles of Deborah and Jael (Judges 4 \& 5) becomes imperative to relating the heroic event to the accolade of Ikwuano-Igbo women protest in 1929 championed by Nwanyeruwa and the Oloko Trios.

\section{Heroic War of Deborah and Jael in Ancient Israel}

War in ancient Israel was directed by God under the theocratic government (2 Chron 6:34-35) and Yahweh was considered to be a warrior, mighty in battle who shatters and scatters His enemies (Exod 15:3, Isaiah 42:13; Zeph 3:17; Ps 24:8; 68:1). Thus, the wars of Israel were regarded as holy wars under the covenantal relationship with God. One of such remarkable wars was the one led by Deborah, the wife of Lappidoth against Jabin, the king of the 
Canaanites residing in Hazor. Deborah whose name means "bee" was called a prophetess because of her special charismatic gift of the Spirit of God that enabled her to judge Israel as a leader between $13^{\text {th }}$ and $12^{\text {th }}$ century BC (Deut 1:44, Judges 6:34). Her headquarters was under "the Palm tree of Deborah" between Ramah and Bethel (Judges 4:5) where she arbitrated and settled disputes for people or leaders of various tribes as a civilian judge with the fear of God.

Deborah's heroic role was in the war she fought to Summon Israel's warriors to the Lord's battle when Israeli soldiers were afraid to combat the Canaanites. King Jabin brutally oppressed Northern Israel especially Naphtali and Zebulun through his Army commander known as Sisera. The men of Israel were weak to defend themselves due to sin until Deborah encourage and charged the unwilling Barak to lead the men of Naphtali and Zebulun to fight the Canaanites.

The war was won by Israel because of the faith and courage of Deborah and Jael respectively. These two women were celebrated in ancient prose and poetry (Judges $4 \& 5$ ) as the heroines of the battle. Jael the wife of Heber the Kenite was praised for her gallant feat, to offer Sisera curdled milk when he requested for water, and her bravery to piece his temple with the tent peg and hammer when he took refuge in her tent.

Sisera felt safe in taking refuge in the tent of Heber because he was a Kenite from the Midianite family who followed the Israelites to the Promised Land through Hobab (the brother-in-Law of Moses - Judges 1:16). So Jabin the king of Hazor did not take these Midianites as his enemies with the Israelites, therefore Sisera felt secured to sleep in Heber's tent and was murdered by Jael who gave him refreshment and stood in guard at the door deceitfully. 
This victory brought restoration to Israel's political and economic freedom from the Canaanites under the auspices of a woman leader - Deborah. Thus, the role of women in the political and economic development of a nation cannot be denied. This episode could be used as a theological background of the Ikwuano women's protest (known as Aba Women War) in 1929 which led to the abolition of women's taxation and warrant chief method of indirect rule by the British imperialists.

\section{Ikwuano-Igbo Women Protest (1929)}

It is interesting to note that the impact of women in 1929 on the economic and political development of Nigeria started among Ikwuano women. It should have been better called "Oloko Women Protest against Women and Domestic Taxation" because it all began in Oloko-Ikwuano under the Old Aba Province. Again, it was a peaceful protest to claim the right of women which was encroached by the Warrant Chief, masterminded by British colonial powers. Unfortunately, the British colony termed it a riot in their apologetic stances. It was not a riot or revolt as wrongly published by the colonialists, hence the thrust of this historical review of the events from indigenous and cultural understanding. Traditionally, Igbo women used peaceful protest with palm fronts which signifies attention for peace, justice, and equity on the issue at the moment. But the colonial rule misunderstood this kind of demonstration by over ten thousand women round Oloko village to claim their human rights in 1929 to be a revolt against the indirect rule through the Warrant Chiefs.

The historical background of the fateful event began when the British Colonialists introduced the system of indirect rule by appointing warrant Chiefs under the District Officers in 1916 to 
influence people and control the native treasury in the then SouthEastern Nigeria. The Government in 1926 ordered for male census through the administrative Officers as the first step of introducing direct taxation of all adult males in 1928 in line with the Native Revenue Ordinance made in 1927. The success of this exercise was not without some conflicting news of upheaval from Calabar and Owerri Provinces that required reassessment and recounting. In September 1929 while Captain Hill was on leave, Captain J. Cook was posted to Bende Division as an Assistant District Officer to take over from Mr. Weir the District Officer.

Captain J. Cook discovered some discrepancies in the census records which were not comprehensive and accurate enough to capture all compounds and families. He zealously introduced a new system of household taxation in which the details of all the wives, children, and livestock in addition to all males in every family must be counted and recorded. This system would probably enable him to have maximum returns of taxes which would boost his Divisional Annual report as had been successfully experimented at Okigwe and Orlu areas. Unfortunately, Oloko women viewed it differently as deliberate and unprecedented oppression against women when the standard of living as high as the price of agricultural produce fell abruptly. Onyirimba (2001) states that the price of a tin of palm oil had fallen from $7 \mathrm{~s} .10 \mathrm{~d}$ in 1928 to $5 \mathrm{~s} .10 \mathrm{~d}$ in 1929 and $50 \mathrm{Ibs}$ of the kernel from 5s.9d in 1928 to $4 \mathrm{~s} .6 \mathrm{~d}$ in 1929 coupled with the daily rise of new customs duties that affected imported articles necessary for daily use. So the women depended solely on their husbands for house up-keep and felt marginalized by such taxation that would involve all wives, boys, girls, and domestic animals. 
In November 1929, a Warrant Chief of Oloko native town known as Chief Okugo in compliance with Captain Cook's instructions sent Mr. Mark Emeruwa, a teacher in the Local NDP Mission to count his people. The messenger entered a compound of a widow known as Nwanyiruwa Ojim who was pressing palm oil and requested her to bring out all her goats, sheep, and so on for census. Oriji (199) observes that Mrs. Nwanyiruwa Ojim was from Ngwa in Aba but married by Late Mr. Ojim from Oloko in Ikwuano. She angrily replied thus to Mr. Emeruwa: "Agurunnegionu?" (Was your mother counted?), a question that traditionally meant that women were not counted during census for taxation. In other words, only men were counted and taxed in those days. Mr. Emeruwa felt insulted and forcefully attempted to accomplish his mission but ended up with a fight that made them seize each other's throats.

Mrs. Nwanyiruwa Ojim narrated her ordeal and assault of Mr. Emeruwa during the women meeting which aggravated the anger of the women against the new women taxation. They sent palm leaves to neighbouring villages inviting them for a demonstration to Chief Okugo's compound and to "sit on" Emeruwa. The "sitting on" culture was the traditional way of protest or demonstration by Igbo women as a sign of disapproval against an offender or a bad ruler which involved surrounding the compound of the culprit with palm leaves and war songs chanted. They did this to call attention to settlement either with payment of fine or withdrawal of a harsh and unexpected policy. This Women Protest later spread to the Divisional Headquarters at Bende where about ten thousand women demanded the withdrawal of Women taxation and removal of Okugo as a Warrant Chief of Oloko. The women protest reached Aba, Owerri, and Calabar Provinces which 
claimed over fifty-five lives of women when the police (Kotuma) opened fire to scare the angry mob. Eventually, Chief Okugo was charged with assault with two years imprisonment by Captain Hill. The Women, children, and domestic animal's taxation was suspended and women were allowed to participate in political affairs in the Native Courts and villages. This in a way reduced hardship and affected the national economy positively. According to Okoro (2006), Madam Mary Okezie was one of the educated women from Ngwa who clearly articulated the women's reports in a memo that was submitted to the commission of inquiry in 1930 .

\section{Impacts of Ikwuano Women Protest of 1929 to National Economic Development}

Despite the trauma caused by the death of about 55 women, the dust that the Women protest in 1929 raised yielded some positive outcomes that shaped the contemporary politics and economy in Nigeria. The positive results include the abolition of the imposition of tax on women, children, and domestic animals; the cancellation of the Warrant Chief method of indirect rule in Igbo land and Nigeria.

Women were employed to work in the native courts. This brought about legal enlightenment and today we can boast of women who have made a positive impact in law, politics, education, medicine, and other disciplines like science and technology. This first public display of feminism announced the competence of women in Nigeria. Not only that it became the beginning of feminism in Nigeria, but it also liberated and lifted men from abject poverty afflicted by the taxation and problems of indirect rule by the colonists. 
The protest championed by Nwanyeruwa and supported by the Oloko Trios led to the improvement of the national economy and respect for human rights to some extent. The Oloko Trios refers to the three women who vehemently allied with Nwanyeruwa in standing against the imposition of taxation on women, their children, and livestock. These trios are Ikonneya, Nwannediya, and Nwaugo. The boldness of these heroines gave hope and liberation to women in their various homes, communities, and society at large. Women's hidden talents and potentials came to the lime light and these brought encouragement and support to the men in agriculture, trade, and politics. Things changed for good until the deflation gradually subsided.

The imperialists started becoming weak in their oppression and indirectly. The way for Nigerian independence was paved gradually through this audacity. This spirit gingered Margret Ekpo to form Aba Market Association in 1946 at the age of 15 as observed by Okoro (2006). Today Ariaria Market Aba in Abia State is an International Market that manufactures shoes, clothes, bags, belts, and other important materials. This market needs urgent Federal attention and renovations in the meantime, for maximum productivity. Road/bridge constructions and renovations of the market should be done to maintain an international standard. Again, industries for processing Agricultural produce and food storage should be built in Ikwuano Local Government Area of Abia State Nigeria, so that the labour of these heroines will not be in vain.

\section{Recommendations}

This paper recommends that women can do more in building and developing the national politics and economy starting from the home if not relegated or silenced with gender inequality. Lessons 
from Deborah's and Jael's exploits in Judges 4 show that the empowerment of Ikwuano Women, adequate support of the Government in revitalizing the production of cash crops in Ikwuano through mechanization and mass employment of indigenous youth would alleviate poverty in the area.

Federal intervention in Ikwuano fertile areas is urgently needed on the reconstruction of roads, equipping the National Root and Crop Research Institute Umudike with food processing/storage facilities to improve our locally produced crops and food. The government and noblemen should not shy away from their responsibilities in supporting women. Barak helped Deborah and Jael to combat King Jabin, Sisera, and the Canaanite soldiers. The complementary approach yielded the attainment of this great feat.

The large fertile acres of land in Ikwuano should be utilized for industry and cash crop production for consumption cum exportation. This is because crops like cocoa, rubber, timber, rice, maize, yam, and cassava are produced in large quantities in Ikwuano. The Local Government should also work hard to advertise locally produced cash crops by investing in cultivating and marketing Ikwuano Rice. Again, major markets like Ndoro and Ariam Markets should be renovated into standard daily markets where agricultural produce will be constantly available for buyers in wholesales. These will attract international bodies to invest more and thereby creating job opportunities for women and youth in rural areas.

\section{Conclusion}

Ikwuano women ignited the protest of 1929 which cancelled the Warrant Chief method of indirect rule and led to the national economic improvement of the British Colonial administration. This 
traditional protest was erroneously published as "Aba Women Riot" by foreign authors who were ignorant of Igbo traditional women's right of protest with palm leaves and the 'sitting on' method against offenders. Similarly, the episode of Deborah and Jael in Judges 4 reveals that the place of women in national political and economic freedom cannot be underestimated. Women should be encouraged to maximize their potentials in supporting men politically and economically. Their wealth of emotional and intuitive knowledge can aid in the improvement of the national economy. Hence, Ikwuano women need empowerment to utilize their endowment for national development. Their roles in 1929 women protest should not be thrown to the dust.

Ohaeri Nnaemeka Ndubuwa is of the Department of Theology, Wesley University Ondo, Nigeria. Ohaeri.Ndubuwa@Wesleyuni.Edu.Ng, Ohaerinnaemeka@Gmail.Com \&

Asukwo Edet Oko teaches at the Department of Religious and Cultural Studies, Akwa Ibom State University (AKSU) Asukwooko@Aksu.Edu.Ng;Revasukwo@Yahoo.Com 


\section{References}

Aja, A.A (2007). The basic concept, Issues and Strategies of Peace and Conflict Resolution: Nigeria African Conflict Case Studies. Enugu: Keny and Brothers.

Arinze, F. (1970). Sacrifice in Igbo Religion.Ibadan:University Press.

Beattie, J.(1980). Other Cultures: Aim and, Methods. London: Routledge \& Kegan Paul.

Eboh, M.P.B. (1997). The structure of Igbo Logic as shown in dispute settlement. PortHarcourt: Paragraphics.

Falusi. G. K. (1976). Women from Biblical Perspective. OritaIbadan Journal of Religious Studies. Pp 147-158 Vol X No 2.

Fatokun, S. A. (2018). Women and Leadership in Nigerian Pentecostal. In Studis Historiae Ecclesisticae, Journal of Church History Society of Southern Africa. Pp. 193-205. Vol 32, No 3.

Ironemenefu (2006). The History and Agricultural Products of IbereIkwuano.

Madu, J.E. (2004). Honest to African Cultural Heritage. Onitsha: Coskan.

Meyers, C. (1988). Discovering Eve: Ancient Israelite Women in Context. New York: Oxford University.

Nmah, P. E. (2003). Women's Rights in Igboland. Aba: Soul Winner.

Nmah, P.E. (2008). Religion and society in African. Enugu: Rabboni.

Nmah, P.E. (2009). Conflicts between Two Religious Cultures: Adhering Reconciliation. Journal of Religion and Human Relations, 24 - 40. 
Nwanegbo, C.J. (2005). Internal Conflict, African Development: An overview of Nigeria situation. Awka: Pond.

Obi, S. N. C. (1972). The Customary Law Manual of Customary Laws obtaining in the Anambra and Imo States of Nigeria. Enugu: Government Press.

Obijole, O. O. (2019). Women Leadership in Pauline Thoufgt and in the Nigerian Pentecostal Churches' Comparative Context. In S. A. Fatokun, African Christianity in Local and Global Contexts. Pp 244-260. Ibadan: Baptist Press.

Okafor F. U. (1992). Igbo Philosophy of Law. Enugu: Fourth Dimension Publishing Co.

Onyirimba, S. (2001). Ikwuano Book of records: A biographicial history Cambridge University Press. Vol.1. Lagos: Eddy.

Pfeiffer, C. F. \& Howard F. V. \& J. Rea (2003). Wyclifs Bible Dictionary. Massachusetts: Hendrickson.

Swidler, L. (1979). Biblical Affirmations of Women. Philadelphia: Westminster.

Uchendu, V. (1965). The Igbo of Southeast Nigeria. London: Holt, Rinehart and Winstan, Inc.

Okoro, U. N. (2006). Ngwa Women, Past, Present \& Future. Owerri: Barloz Publishers.

Oriji, J. (199). Ngwa History: A Study of Social and Economic Changes in Igbo mini-states in time perspective. New York: Castle. 